\title{
Effects of a Lifestyle Interventions Program on Quality of Life in Breast Cancer Survivors
}

\author{
Haleh GHAVAMI ${ }^{1,2}$, Neriman AKYOLCU ${ }^{1}$ \\ ${ }^{1}$ Istanbul University, Florence Nightingale Nursing Faculty, Istanbul, TURKEY \\ ${ }^{2}$ University of Medical Sciences, Nursing and Midwifery Faculty of Urmia, IRAN
}

\begin{abstract}
Many breast cancer survivors want to know what proactive steps they can take in addition to conventional therapies to positively impact their prognosis. This study was planned to compare the effects of a lifestyle interventions program, to usual care on; quality of life (QOL) in breast cancer survivors. This randomized controlled trial study was carried between 2012 and 2015 and included 80 women with stage I, II, or III breast cancer. They were divided into two groups randomly; 40 women were randomized to the lifestyle interventions group, and 40 to the usual care group. Those in the lifestyle interventions group were instructed to practice supervised aerobic exercises with dietary energy restriction training for 24 weeks. Those in the usual care group were instructed to continue their normal life. The patient characteristics form and EORTC QLQ-C30 were used for data collection. Controlling for baseline scores, change over time between two groups was significantly different for the women who practiced in lifestyle interventions; this group reported significantly improved $Q O L$ as compared to control group $(p<0.001)$. Breast cancer patients may benefit from participating in lifestyle interventions program for improving their quality of life. Additional research in lifestyle interventions along with cognitive behavioral therapy also may be beneficial.
\end{abstract}

Keywords: Breast cancer, Healthy diet, Lifestyle, Physical activity, Quality of life

ÖZET

Meme Kanserli Hastalarda Yaşam Tarzı Müdahalelerinin Yaşam Kalitesi Üzerine Etkisi

Meme kanserinden kurtulanların birçoğu, prognozunu olumlu şekilde etkilemek için geleneksel tedavilere ek olarak herhangi proaktif adımları atabileceğini bilmek ister. Bu çalışma bir yaşam tarzı müdahale programının , yaşam kalitesi üzerine etkisini değerlendirmek için planlanmıştır. Bu randomize kontrollü deneme çalışması 2012-2015 yılları arasında gerçekleştirildi ve evre I, II veya III meme kanseri olan 80 kadını kapsıyordu. Hastalar rastgele yöntemi ile iki gruba ayrıldı; 40 kadın yaşam tarzı müdahale grubuna, 40'ı normal bakım grubuna randomize edildi. Yaşam tarzı müdahale grubundaki kadınlara, 24 haftalık diyet enerjisi kısıllama eğitimi ile denetlenmiş aerobik egzersiz uygulandı. Normal bakım grubundaki kadınlardan normal hayatlarını sürdürmeleri istendi.Veri toplama için hasta özellikleri formu ve EORTC QLQ-C30 kullanıldı. Uygulama öncesi deney ile kontrol grubu QLQ-C30 ortalama puan arasında istatistiksel olarak anlamlı herhangi bir farklllk saptanmazken; uygulama sonrası yaşam tarzı müdahaleleri grubunda bu puanların , kontrol grubundaki hastaların puan ortalamalarına göre istatistiksel olarak anlamlı derecede farklı bulundu ( $p<0.001)$. Meme kanseri hastaları yaşam kalitelerini yükseltmek için yaşam tarzı müdahalelerine katılmaktan fayda görebilirler. Yaşam tarzı müdahalelerinde bilişsel davranış terapisi ile ilgili ilave araştırmalar da yararlı olabilir.

Anahtar Kelimeler: Meme kanseri, Sağlıklı beslenme, Yaşam tarzı, Fiziksel aktivite, Yaşam kalitesi 


\section{INTRODUCTION}

Breast cancer is the most common solid malignancy in women aged 20-59 years and the second most common, after lung cancer, in women aged 60 years and older. ${ }^{1}$ Breast cancer ranks first among the most commonly seen cancer types in women with an incidence of $41.8 \%$ in Turkey. Its incidence rate is 79.5 per 100.000 among the women aged 40 and 44, while it may increase to 127.9 per 100.000 among the women aged 65 and 68.7. ${ }^{2}$ In general there are two types of breast cancer risk factors: those which can be influenced by a woman herself (e.g., lifestyle) and those which cannot be influenced (e.g., family history). Aspects of nutrition and lifestyle may be largely responsible for the development of common cancers in Western countries, as indicated by the large differences in breast cancer rates in different countries as well as the striking changes in these rates among migrating populations and the rapid changes over time within countries. ${ }^{3}$

Breast cancer and its treatments often are associated with adverse effects that can persist for years and decrease health related quality of life (QOL) ${ }^{4}$ Recently, besides measurable tumor parameters, the subjective perception regarding quality of life has become an important therapeutic objective. This is true both in the early stages when women seek to participate in everyday life and in the metastatic setting. Many recent major trials have employed QOL as secondary endpoint. ${ }^{5}$ On the other hand evidence suggests that lifestyle behaviors such as regular exercise and a healthy diet can improve health-related QOL and relieve symptom problems and mood disturbances 4 , but population-based surveys suggest that cancer survivors are less likely than non-cancer populations to practice lifestyle behaviors. ${ }^{6}$ Reduced physical activity during cancer treatment can decrease the capacity for physical performance, and activity may be further limited by the late effects of cancer and its treatment in survivors. Breast cancer survivors with lower levels of physical activity have a higher risk for premature death. ${ }^{7}$ Quality of Life is an area of increasing interest among healthcare practitioners caring for vulnerable populations. QOL measures have been used to direct outcome criteria in breast cancer research, to set healthcare policy, and to help identify problems associated with disease, medical management, and effectiveness of rehabilitative interventions. ${ }^{8}$ It has been shown that during the post-acute care stage, cancer survivors may initiate diet, physical activity and other lifestyle changes in an attempt to prevent recurrence or chronic disease or to improve overall health and quality of life ${ }^{9}$, but cancer survivors do not routinely receive counseling by healthcare professionals on lifestyle habits linked to an improved quality of life and prolonged survival, particularly physical activity. ${ }^{10}$

Accordingly, this study assessed the impact of lifestyle intervention on quality of life (QOL); our primary outcome. We hypothesized that lifestyle interventions program would enhance quality of life relative to those in the control group.

\section{PATIENTS AND METHODS}

\section{Research Setting and Sample}

The study samples were 80 women that were operated on for breast cancer and completed their chemotherapy or radiation therapy 3-18 months ago in Urmia University of Medical Sciences and Omid Charity Oncology Center, Urmia, Iran. They were divided randomly into two groups: control group and active lifestyle interventions program group. The researcher used a random numbers table to assign participants who met all criteria to either the intervention group or the control group in equal numbers.

\section{Details of Power Calculations and Sample Size}

Body weight was chosen as the primary outcome variable for calculation of sample size. Utter et al. (1998) reported $8.1 \mathrm{~kg}$ reduction in body weight in obese women following a 12-week lifestyle intervention, incorporating moderate dietary energy restriction in conjunction with exercise. ${ }^{11}$ Body weight changed from a baseline \pm SD level of $89.9 \pm 11.7$ to $81.8 \pm 10.8 \mathrm{~kg}$ following the intervention. ${ }^{11}$ This amount of weight loss is associated with improved physical and psychological health in obese women.$^{11}$ On the basis of these data, and taking into account an expected patient drop-out of up to $10 \%$ (based on the drop-out rate in our ongoing trial with breast cancer survivors. ${ }^{11}$ We concluded recruitment of 40 patients for each group could give us $90 \%$ power to detect a difference in 
body weight of $8 \mathrm{~kg}$ at $\alpha$ level of 0.05 . So we registered 80 patients (40 for each group).

Patient Inclusion Criteria: a) women with a BMI $>25$ and classified as disease stage I-III; b) patients must have completed breast cancer primary treatment (surgery, chemotherapy, radiotherapy) at least three months ago, and not more than 18 months ago; c) patients on (Nolvadex ; Tamoxifen) and other endocrine treatments but not hormone replacement therapy (HRT) will be included; d) patients must be willing and able to attend supervised exercise sessions at least 3 times per week for a period of 24 weeks, with the intention of achieving an $80 \%$ minimum compliance target for attendance; e) patients must be adults (18 years and above); f) patients must be able to read and write in Persian; g) have a certificate from a cardiologist to participate in exercise sessions.

Patient Exclusion Criteria: a) metastatic breast cancer patients and patients with inoperable or active loco-regional disease; b) patients following alternative/complementary diets or taking high dose antioxidant supplement; c) patients with a physical/psychiatric impairment that would seriously impair their physical mobility; d) patients who were suffering from severe nausea, anorexia or other diseases affecting health (e.g. arthritis and multiple sclerosis). e) use of HRT or oral contraceptives within the past four months (HRT is not commonly prescribed in women who are recovering from breast cancer treatment); f) patients who were engaged in exercise at the beginning of study (two or more times per week for at least $30 \mathrm{~min}$ per session during the previous 3 months); g) patients who are unable for other reasons to continue to participate in research.

\section{Data Collection and Instruments}

Data were obtained from the patient information form and EORTC QLQ-C30 (version 3.0) questionnaire. All patients in case and control groups were asked to complete these questionnaires before and after the intervention. The patient information form was researcher-made form.

The EORTC (European Organization of Research and Treatment for Cancer) QLQ-C30 version 3.0 is a 30-item core cancer-specific questionnaire measuring QOL in cancer patients 12 and incorporates five functional scales; physical (PF), role (RF), cognitive (CF), emotional (EF) and social (SF), three symptom scales for fatigue, pain and nausea/ vomiting, a global health QOL scale, and several single items for the perceived financial impact of disease and treatment and for the assessment of additional symptoms such as dyspnoea, appetite loss, sleep disturbance, constipation and diarrhea, which are commonly reported by cancer patients. All items were scored on 4-point Likert scales ranging from 1 (not at all) to 4 (very much). As an exception, item 29 and 30 in the global health QOL subscale were scored on a modified 7-point linear analogue scale. ${ }^{12}$ The Persian Version of the QOL-C30 that was developed by Montazeri et al. in 199913 was used in this study. The scoring of the EORTC QLQ-C30 was performed according to the EORTC scoring manual. ${ }^{12}$ The content validity of the Persian version of EORTC QLQC30 and its reliability were calculated (Cronbach's alpha coefficient, $r=$ 0.90)..$^{13}$ In our study of the EORTC QLQC30 scale, Cronbach's alpha reliability coefficient $(\alpha)$ in the first measurement was 0.758 , and it was calculated as 0.768 in the last measurement.

\section{Ethical Considerations and Procedures}

The study was approved by the administration of the Istanbul University Institute of Health Sciences and Urmia University of Medical Sciences. Participants were informed of the study, and consents were obtained.

Then a total of 80 women (according to the sample acceptance and Rejection Criteria of study) were randomized to the active lifestyle interventions group and to the control group. The patients in the control group were instructed to continue normal activities. Patients in the lifestyle interventions group were instructed to the following manipulations.

Supervised aerobic exercise: Patients randomized to the active lifestyle interventions attended moderate-intensity aerobic exercise sessions on three to five days per week for a period of 24 weeks under the supervision of researcher and an exercise coach.

To account for differences in daily patterns of fatigue and to minimize attrition, patients were offered different times to choose from, including 
weekends. Patients were encouraged to attend five supervised sessions each week and had to try to attend at least three of the sessions. Patients not able to attend five supervised sessions were counseled on how they could fit an extra 1-2 home/community-based exercise sessions into their weekly routine. Supervised exercise was performed in groups of up to fifteen participants in an exercise room that contained a variety of aerobic exercise equipment. Each session comprised a 10-minute warm-up period (involving light aerobic exercise and a gentle range of motion exercises), 30 minutes of aerobic exercise at an intensity of $70 \%-85 \%$ heart rate reserve, and a 10-minute cool-down period involving lower intensity aerobic exercise and some light stretching. Patients were also offered a range of aerobic exercise modalities at these sessions (e.g. stepping, cycling, \& walking/jogging) to promote enjoyment and to aid compliance with the program. Patients were encouraged to use their preferred exercise mode to strengthen the possibility they would maintain a physically active lifestyle when the supervised exercise program had been completed. The exercise therapy sessions used a variety of positive attitudes and experiences for promoting exercise adherence.

Dietary energy restriction: Patients randomized to active lifestyle intervention received individualized healthy eating dietary advice and written information. The focus of the verbal advice was on reducing the patient's total daily calorie intake to $600 \mathrm{kcal}$ below their calculated energy requirements. Individual energy requirements were estimated from formulae of basal metabolic rate and physical activity level. The aim of this strategy was to induce a steady weight loss of up to $0.5 \mathrm{~kg}$ each week. In addition, the overall quality of the diet was examined with a view to (i) reducing the dietary intake of fat to $25 \%$ of the total calories, (ii) eating at least 5 portions of fruit and vegetables a day, (iii) increasing the intake of fiber and reducing refined carbohydrates. Once a week, patients met with the researcher who discussed their individual diet diaries with them and identified ways which they could further improve their nutritional intake.

\section{Statistical Analysis}

SPSS (Statistical Package for Social Sciences) software for Windows 17.0 was used for statistical analysis. Numbers shown as a percentage and average for identifying characteristics of patients, Mann-Whitney U and chi-square tests were used for evaluating the statistical significance in sociodemographic data, disease characteristics, QLQC30 scores between the experimental and control groups before and after the study. Results were accepted at the confidence interval of $95 \%$ and the statistical significance level of $p<0.05$.

\section{RESULTS}

\section{Demographic or Medical Characteristics}

Patients included in the study were compared to each other regarding variables such as age, marital status, education level, employment status, number of children, lactation number, duration of breastfeeding, comorbidities, other medication use, surgical procedures applied to the breast, chemotherapy, radiotherapy, use of Tamoxifen, and duration of Tamoxifen use that might affect the results of the research. No baseline differences existed between the two groups for either demographic or medical characteristics and groups were similar together ( $>>0.05$, Tables 1, 2).

\section{Quality of Life (QLQ-C30)}

No baseline differences existed between the two groups for the mean of QLQ-C30 subscale scores ( $p>0.05$ ) before the study, but the differences in physical functioning, emotional functioning, role function, cognitive functions, social function, global health status /QOL, pain, nausea vomiting, fatigue, dyspnea, insomnia, appetite loss, constipation, diarrhea and financial difficulties, subscale scores between the two groups of study were statistically significant $(\mathrm{p}<0.001)$ after the intervention. These results showed significantly better symptom relief, functional and global health status in the lifestyle intervention group than in the control group after the intervention (Table 3 ).

\section{Limitations}

As one of the main limitations in the field of nutritional science is that food and nutrients are not consumed in isolation and, from an epidemiological point of view, form a complex network of correlated influences. Therefore, it is difficult to study dietary patterns, which simultaneously reflect these exposures ${ }^{14}$, so one of the limitations of our 


\begin{tabular}{|c|c|c|c|c|c|c|c|c|}
\hline \multirow[b]{2}{*}{ Characteristics } & \multirow{2}{*}{$\begin{array}{l}\text { Total }(n=80) \\
n\end{array}$} & \multicolumn{2}{|c|}{$\begin{array}{l}\text { Active Lifestyle } \\
\text { Intervention }(n=40)\end{array}$} & \multicolumn{2}{|c|}{ Control $(n=40)$} & \multirow[b]{2}{*}{$\%$} & \multirow[b]{2}{*}{$\chi^{2 / z}$} & \multirow[b]{2}{*}{$\mathbf{p}$} \\
\hline & & $\%$ & $\mathbf{n}$ & $\%$ & $\mathbf{n}$ & & & \\
\hline Age (Mean $\pm S D)$ & $48.99 \pm 9.42$ & $48.75 \pm 9.49$ & $49.23 \pm 9.46$ & -0.236 & 0.813 & & & \\
\hline Marital status & & & & & & & - & 1.000 \\
\hline Single & 3 & 3.8 & 2 & 5.0 & 1 & 2.5 & & \\
\hline Married & 77 & 96.2 & 38 & 95.0 & 39 & 97.5 & & \\
\hline Level of education & & & & & & & 0.195 & 0.978 \\
\hline Primary & 19 & 23.7 & 9 & 22.5 & 10 & 25.0 & & \\
\hline Secondary school & 7 & 8.8 & 4 & 10.0 & 3 & 7.5 & & \\
\hline High school & 40 & 50.0 & 20 & 50.0 & 20 & 50.0 & & \\
\hline Greater than high school & 14 & 17.5 & 7 & 17.5 & 7 & 17.5 & & \\
\hline Working Status & & & & & & & 0.063 & 0.802 \\
\hline House wife & 58 & 72.5 & 30 & 75.0 & 28 & 70.0 & & \\
\hline Employee & 22 & 27.5 & 10 & 25.0 & 12 & 30.0 & & \\
\hline Child having & & & & & & & - & 0.675 \\
\hline Yes & 74 & 92.5 & 36 & 90.0 & 38 & 95.0 & & \\
\hline No & 6 & 7.5 & 4 & 10.0 & 2 & 5.0 & & \\
\hline $\begin{array}{l}\text { Number of children } \\
\text { (mean } \pm \text { SD) }\end{array}$ & $2.57 \pm 1.40$ & $2.58 \pm 1.34$ & $2.55 \pm 1.46$ & -0.192 & 0.848 & & & \\
\hline Lactation $(n=74)$ & & & & & & & - & 1.000 \\
\hline Yes & 68 & 91.9 & 33 & 91.7 & 35 & 92.1 & & \\
\hline No & 6 & 8.1 & 3 & 8.3 & 3 & 7.9 & & \\
\hline Lact. period(mean \pm SD) & $39.92 \pm 28.71$ & $42.11 \pm 30.91$ & $37.84 \pm 26.72$ & -0.440 & 0.660 & & & \\
\hline Comorbidity & & & & & & & 0.000 & 1.000 \\
\hline Yes (HTN) & 27 & 33.8 & 14 & 35.0 & 13 & 32.5 & & \\
\hline No & 53 & 66.3 & 26 & 65.0 & 27 & 67.5 & & \\
\hline
\end{tabular}

study should be noted in interpreting outcomes of our trial. Also it is important to note other limitations of this study such as relatively a small sample size, program location, scheduling conflicts, and transportation. Our ability to achieve statistically significant results at the 6-month assessment periods was limited by the small sample size of study participants. The limitation of enrolling patients from two institutions also contributed to the small study population, as many eligible patients could not participate in the exercise program due to location, transportation limitations, and conflicts in schedule.

In the future, additional research should address some of the limitations of this study by evaluating the impact and sustainability of a more comprehensive lifestyle intervention program that incorporates both exercise and nutrition in a larger multi-institutional population.

\section{DISCUSSION}

This randomized controlled trial study was planned to compare the effects of a lifestyle interventions program, to usual care on; quality of life (QOL) in breast cancer survivors. Our study findings support our priori hypothesis that lifestyle interventions among women with breast cancer can improve their quality of life.

Numerous studies have indicated that exercise during and after cancer therapy can improve physical functioning, QOL, and cancer-related fatigue in cancer survivors. ${ }^{15-19}$

Kim et al. ${ }^{4}$ in 2011, investigated the feasibility and preliminary effects of a simultaneous stagematched exercise and diet (SSED) intervention in breast cancer survivors through a randomized, controlled trial in South Korea. Their samples were 45 women with breast cancer who completed their cancer therapy. Participants were assigned to 


\begin{tabular}{|c|c|c|c|c|c|}
\hline \multirow[b]{2}{*}{ Characteristics } & \multirow{2}{*}{$\begin{array}{l}\text { Total }(n=80) \\
n(\%)\end{array}$} & \multirow{2}{*}{$\begin{array}{l}\text { Active Lifestyle } \\
\text { Intervention }(n=40) \\
n(\%)\end{array}$} & \multicolumn{3}{|l|}{$\begin{array}{l}\text { Control } \\
(n=40)\end{array}$} \\
\hline & & & n (\%) & $\chi^{2}$ & p \\
\hline Surgery type & & & & - & 0.241 \\
\hline Mastectomy & 77 (96.3) & 37 (92.5) & $40(100.0)$ & & \\
\hline $\begin{array}{l}\text { Breast-conserving surgery } \\
\text { Chemotherapy }\end{array}$ & $3(3.8)$ & $3(7.5)$ & $0(0.0)$ & & \\
\hline Yes & $80(100.0)$ & $40(100.0)$ & $40(100.0)$ & - & - \\
\hline Radiotherapi & & & & & \\
\hline Yes & $80(100.0)$ & $40(100.0)$ & $40(100.0)$ & - & - \\
\hline Tamoksifen using & & & & 0.000 & 1.000 \\
\hline Yes & $46(57.5)$ & $23(57.5)$ & $23(57.5)$ & & \\
\hline No & $34(42.5)$ & $17(42.5)$ & $17(42.5)$ & & \\
\hline
\end{tabular}

the SSED intervention group $(n=23)$ or a control group $(n=22)$. Participants in the SSED group received a 12-week individualized intervention promoting prescribed exercise and a balanced diet through stage-matched telephone counseling and a workbook. Main research variables were: Program feasibility, behavioral outcomes (stage of motivational readiness for exercise and diet, physical activity, and diet quality), and quality-of-life (QOL) outcomes (functioning and global QOL, fatigue, anxiety, and depression). Their results showed that; participant evaluations of the SSED intervention indicated that it was feasible and acceptable. All women felt that the overall intervention contents were appropriate, and $95 \%$ believed that the intervention helped to promote healthy behaviors. Objective data also supported the SSED intervention's feasibility (i.e., $91 \%$ completed the trial and $100 \%$ of intervention calls were received). When compared to control, the SSED intervention group showed significantly greater improvement in motivational readiness for exercise and diet, emotional functioning, fatigue, and depression. They concluded; preliminary results suggest that the SSED intervention delivered via telephone counseling and workbook is feasible and beneficial for positive behavioral and QOL outcomes.4 Results of our study were consistent with the results of this study on improving quality of life.

Another consistent research with our study carried out by Mohammadi et al. 20 in 2013; aimed to determine association between healthy eating habits and physical activity with quality of life among Iranian breast cancer survivors. A total of 100 Iranian women, aged between 32 to 61 years were recruited to participate in this cross-sectional study. Eating practices were evaluated by a modified questionnaire from the Women's Healthy Eating and Living (WHEL) study. Physical activity was assessed using the International Physical Activity Questionnaire (IPAQ). EORTC QLQ-C30/+BR-23 were applied to determine quality of life. Approximately $29 \%$ of the cancer survivors were categorized as having healthy eating practices, $34 \%$ had moderate eating practices and $37 \%$ had poor eating practices based on nutrition guidelines. The study found positive changes in the decreased intake of fast foods $(90 \%)$, red meat $(70 \%)$ and increased intake of fruits $(85 \%)$ and vegetables $(78 \%)$. Generally, breast cancer survivors with healthy eating practices had better global quality of life, social, emotional, cognitive and role functions. Results showed that only 12 women (12\%) met the criteria for regular vigorous exercise, $22 \%$ had regular moderate-intensity exercise while the majority (65\%) had low-intensity physical activity. They concluded; breast cancer survivors with higher level of physical activity had better emotional and cognitive functions. Healthy eating practices and physical activity could improve quality of life of cancer survivors. ${ }^{20}$ Our samples were Iranian breast cancer survivors too, also our intervention improved EORTC QLQ-C30 . 
International Journal of Hematology and Oncology

\begin{tabular}{|c|c|c|c|c|c|c|c|c|c|}
\hline \multirow[b]{2}{*}{ Functional scales } & \multirow[b]{2}{*}{ Group } & \multicolumn{4}{|c|}{ Before intervention } & \multicolumn{4}{|c|}{ After intervention } \\
\hline & & Mean & SD & $z^{a}$ & p & Mean & SD & $z^{a}$ & p \\
\hline \multirow[t]{2}{*}{ Global health status / QoL } & intervention $(n=40)$ & 57.50 & 15.19 & -0.044 & 0.965 & 91.25 & 8.00 & -7.429 & $<0.001^{*}$ \\
\hline & Control $(n=40)$ & 57.49 & 15.19 & & & 57.28 & 14.01 & & \\
\hline \multirow[t]{2}{*}{ Physical functioning } & intervention $(n=40)$ & 67.16 & 15.57 & -0.142 & 0.887 & 93.00 & 5.00 & -6.519 & $<0.001^{*}$ \\
\hline & Control $(n=40)$ & 67.50 & 15.78 & & & 72.00 & 17.49 & & \\
\hline \multirow[t]{2}{*}{ Role functioning } & intervention $(n=40)$ & 75.00 & 26.42 & -0.377 & 0.706 & 97.08 & 6.41 & -4.541 & $<0.001^{*}$ \\
\hline & Control $(n=40)$ & 74.58 & 24.16 & & & 81.66 & 19.54 & & \\
\hline \multirow[t]{2}{*}{ Emotional functioning } & intervention $(n=40)$ & 58.36 & 26.67 & -0.503 & 0.615 & 87.91 & 14.49 & -4.495 & $<0.001^{*}$ \\
\hline & Control $(n=40)$ & 54.20 & 28.69 & & & 62.91 & 26.48 & & \\
\hline \multirow[t]{2}{*}{ Cognitive functioning } & intervention $(n=40)$ & 69.58 & 23.84 & -0.537 & 0.592 & 96.25 & 7.05 & -5.014 & $<0.001^{*}$ \\
\hline & Control $(n=40)$ & 73.50 & 18.33 & & & 78.50 & 18.83 & & \\
\hline \multirow[t]{2}{*}{ Social functioning } & intervention $(n=40)$ & 65.41 & 27.58 & -1.425 & 0.154 & 92.08 & 13.07 & -4.814 & $<0.001^{*}$ \\
\hline & Control $(n=40)$ & 57.50 & 25.30 & & & 65.00 & 26.64 & & \\
\hline Symptom scales / items & Group & Mean & SD & $z^{a}$ & p & Mean & SD & $z^{a}$ & p \\
\hline \multirow[t]{2}{*}{ Fatigue } & intervention $(n=40)$ & 42.50 & 23.45 & -0.226 & 0.821 & 3.06 & 5.62 & -7.067 & $<0.001^{*}$ \\
\hline & Control $(n=40)$ & 43.05 & 22.95 & & & 36.66 & 21.23 & & \\
\hline \multirow[t]{2}{*}{ Nausea and vomiting } & intervention $(n=40)$ & 14.58 & 19.68 & -0.399 & 0.69 & 1.65 & 5.02 & -3.942 & $<0.001^{\star}$ \\
\hline & Control $(n=40)$ & 15.83 & 19.59 & & & 12.50 & 14.49 & & \\
\hline \multirow[t]{2}{*}{ Pain } & intervention $(n=40)$ & 40.41 & 24.72 & -0.373 & 0.709 & 4.17 & 7.31 & -6.724 & $<0.001^{\star}$ \\
\hline & Control $(n=40)$ & 42.08 & 24.16 & & & 37.50 & 22.25 & & \\
\hline \multirow[t]{2}{*}{ Dyspnoea } & intervention $(n=40)$ & 35.83 & 23.13 & -0.854 & 0.393 & 2.50 & 8.89 & -4.398 & $<0.001^{*}$ \\
\hline & Control $(n=40)$ & 31.66 & 23.81 & & & 20.83 & 22.25 & & \\
\hline \multirow[t]{2}{*}{ Insomnia } & intervention $(n=40)$ & 50.00 & 23.87 & -0.464 & 0.643 & 3.33 & 10.13 & -7.037 & $<0.001^{*}$ \\
\hline & Control $(n=40)$ & 52.50 & 24.91 & & & 43.33 & 22.89 & & \\
\hline \multirow[t]{2}{*}{ Appetite loss } & intervention $(n=40)$ & 18.33 & 19.90 & -0.313 & 0.754 & 0.00 & 0.00 & -3.73 & $<0.001^{*}$ \\
\hline & Control $(n=40)$ & 20.00 & 21.08 & & & 10.00 & 15.47 & & \\
\hline \multirow[t]{2}{*}{ Constipation } & intervention $(n=40)$ & 20.83 & 22.25 & -0.602 & 0.547 & 2.50 & 8.89 & -3.836 & $<0.001^{\star}$ \\
\hline & Control $(n=40)$ & 24.16 & 23.85 & & & 25.00 & 54.30 & & \\
\hline \multirow[t]{2}{*}{ Diarrhoea } & intervention $(n=40)$ & 10.83 & 23.13 & -0.401 & 0.688 & 0.83 & 5.27 & -2.909 & $<0.001^{*}$ \\
\hline & Control $(n=40)$ & 10.83 & 19.08 & & & 9.17 & 16.86 & & \\
\hline \multirow[t]{2}{*}{ Financial difficulties } & intervention $(n=40)$ & 39.16 & 28.13 & -0.108 & 0.914 & 10.00 & 15.47 & -3.889 & $<0.001^{*}$ \\
\hline & Control $(n=40)$ & 38.33 & 25.65 & & & 31.66 & 26.09 & & \\
\hline Mann Whitney U test & ${ }^{*}=p<0.001$ & & & & & & & & \\
\hline
\end{tabular}

Phillips and McAuley ${ }^{21}$ in 2014 conducted a study entitled; Physical activity and quality of life in breast cancer survivors: the role of self-efficacy and health status. They aimed to longitudinally test a model examining self-efficacy and health status as potential mediators of this relationship. At baseline and 6 months, breast cancer survivors ( $\mathrm{n}=$ 1527) completed physical activity, self-efficacy, health status, and QOL measures, and a subsample $(n=370)$ wore an accelerometer. Panel analysis within a covariance modeling framework was used to test the hypothesis that physical activity indirectly influences QOL across time. Their results showed that: The hypothesized model provided a good fit in the full sample $\left(\chi^{2}=409.06\right.$; d.f. $=91$, $\mathrm{p}<0.001$; comparative fit index $(\mathrm{CFI})=0.98$; standardized root mean residual $(\mathrm{SRMR})=0.04)$ and the accelerometer subsample $\left(\chi^{2}=320.96\right.$, d.f. $=134$, $\mathrm{p}<0.001 ; \mathrm{CFI}=0.95 ; \mathrm{SRMR}=0.05)$, indicating that physical activity indirectly, via self-efficacy and health status indicators, influences QOL across time. They concluded; physical activity may influence QOL in breast cancer survivors through more proximal, modifiable factors. 21 The results of our study were consistent with the results of this study too. Also, the randomized intervention trial of Schmidt et al..$^{22}$ (2014) in breast cancer patients indicated a beneficial impact of resistance exercise 
during chemotherapy on physical fatigue and quality of life aspects. ${ }^{22}$

Other similar research to our study, carried out by Canário et al. ${ }^{23}$ in 2016 .They evaluated the relationship between levels of physical activity, fatigue and quality of life (QOL) in women diagnosed with breast cancer. 215 women between the ages of 40 and 65 years were recruited at a cancer clinic. Physical activity levels were assessed by using the International Physical Activity Questionnaire (IPAQ), fatigue levels by using the revised Piper scale, and QOL by means of EORTC QLQ-C30 and WHOQOL-Bref. Their results showed that; mean scores for QOL were significantly lower among fatigued women $(\mathrm{p}<0.001)$. More active women scored higher on all scales of QOL (EORTC), especially for functional capacity ( $\mathrm{p}<0.001$ ), compared with the sedentary patients. A significant association was found between level of physical activity and overall QOL (WHOQOL-Bref) for all domains $(\mathrm{p}<0.001)$. They concluded: physical activity appears to positively influence fatigue and QOL in women diagnosed with breast cancer. ${ }^{23}$

Saarto et al. ${ }^{24}$ in 2012 conducted a randomized trial entitled; effectiveness of a 12-month exercise program on physical performance and quality of life of breast cancer survivors. A total of 573 breast cancer survivors were assessed 12 months after adjuvant treatments by means of a $2 \mathrm{~km}$ walk, run test, physical fitness and QOL evaluation (EORTC). Results detected a positive correlation between increased physical activity and improved quality of life.24 Although our interventions duration was 24 weeks, the results of our study were consistent with the results of this study too.

There is one study that its results are in controversy with the results of our study on quality of life (QOL- C30) after applying exercise intervention. In two university hospitals in Copenhagen, Denmark a supervised multimodal exercise intervention (including high and low intensity components that was feasible and could safely be used in patients with various cancers who were receiving adjuvant chemotherapy or treatment for advanced disease) applied for six weeks on 269 patients with cancer; 73 men, 196 women, mean age 47 years (range 20-65) representing 21 diagnoses. Main exclusion criteria were brain or bone metastases. 235 patients completed follow-up. The intervention reduced fatigue and improved vitality, aerobic capacity, muscular strength, physical and functional activity, and emotional wellbeing, but not quality of life. ${ }^{25}$ In our opinion this negative result may be related to different diagnoses of their samples, or due to their shorter term of intervention than our intervention duration.

Despite the numerous studies on the positive effects of physical activity, findings regarding specific designs and modes of exercise programs are not yet sufficient. In the future, intervention studies need to focus on exercise modes and dosageresponse effects in order to figure out the optimal effect of physical activity on individual goals. ${ }^{26}$

\section{Conclusions}

Current study showed that breast cancer patients may improve their quality of life from participating in lifestyle interventions. Also this simple, effective, comfortable, and low-cost lifestyle interventions program for breast cancer survivors may apply to other types of cancer patients. Additional research in lifestyle interventions along with cognitive behavioral therapy also may be beneficial. The results of this study may contribute to the growing body of knowledge supporting the feasibility and effectiveness of lifestyle interventions as a nonpharmacologic option for enhancing health related quality of life in the breast cancer survivors. These findings have important practical implications for future physical activity interventions that aim to both secure physiological improvements and longterm exercise continuation for target groups such as cancer survivors. The current authors feel that the involvement of clinicians closest to the patients is valuable in identifying possible interventions to optimize patient care.

\section{Acknowledgements:}

The authors would like to thank so much the volunteers who accepted to participate in this study, and also Prof. Dr. Nevin KANAN, Prof. Dr. Gülbeyaz CAN, Associate Prof. Ikbal ÇAVDAR, Associate Prof. Ayfer ÖZBAŞ and Dr. Mohsen MANSOURI (oncologist) for their valuable suggestions and contributions to this PhD dissertation. Also Mr. Atilla BOZDOGAN deserves special thanks for statistical analysis of this project. 


\section{REFERENCES}

1. Turkman YE, Opong AS, Harris LN, Knobf MT. Triple negative breast cancer outcomes. CJON 19: 62-67, 2015.

2. Duman NB, Yilmazel G, Pinar G, Buyukgonenc L. The risk level of breast cancer and breast cancer awareness among the Turkish women aged 65 years and older. UHOD 25: 60-69, 2015.

3. Gerber B. Options for breast cancer prevention in healthy women. Breast Care 9: 382, 2014.

4. Kim SH, Shin MS, Lee HS, et al. Randomized pilot test of a simultaneous stage-matched exercise and diet intervention for breast cancer survivors. Oncol Nurs Forum 38: E97-106, 2011.

5. Müller V, Fuxius S, Steffens CC, et al. Quality of life under Capecitabine (Xeloda $($ ) in patients with metastatic breast cancer: data from a German non-interventional surveillance study. Oncol Res Treat 37: 748-755, 2014.

6. Karvinen $\mathrm{KH}$, Bruner B,Truant T. Lifestyle counseling practices of oncology nurses in the United States and Canada. CJON 19: 690-696, 2015.

7. Kiecolt-Glaser JK, Bennett JM, Andridge R, et al. Yoga's impact on inflammation, mood, and fatigue in breast cancer survivors: a randomized controlled trial. J Clin Oncol 32: 10401049, 2014.

8. Sammarco A, Konecny LM. Quality of life, social support, and uncertainty among Latina Breast Cancer Survivors. Oncol Nurs Forum 35: 844-849, 2008.

9. Paige EM, Joseph JV, Pamela FS, Terryl JH. Dietary supplement use in adult cancer survivors. Oncol Nurs Forum 36: 6168, 2009.

10. Ruiz-Casado A, Verdugo AS, Solano MJ, et al. Objectively assessed physical activity levels in Spanish Cancer Survivors. Oncol Nurs Forum 41: E12- E20, 2014.

11. Saxton JM, Daley A, Woodroofe N, et al. Study protocol to investigate the effect of a lifestyle intervention on body weight, psychological health status and risk factors associated with disease recurrence in women recovering from breast cancer treatment [ISRCTN08045231]. BMC Cancer 6: 35, 2006.

12. Fayers PM, Aaronson NK, Bjordal K, et al. The EORTC QLQ-C30 scoring manual. 3rd ed. European Organization for Research and Treatment of Cancer, Brussels; 2001 (D/2001/6136/001, ISBN 2-9300 64-22-6). http://www.eortc. be/qol/files/SCManualQLQ-C30.pdf (Access date: 2/12/2017)

13. Montazeri A, Harirchi I, Vahdani M, et al. The EuropeanOrganization for Research and Treatment of Cancer Quality of Life Questionnaire (EORTC QLQC30): translation and validation study of the Iranian Version. Support Care Cancer 7: 400406,1999.

14. Ferrini K, Ghelfi F, Mannucci R, Titta L. Lifestyle, nutrition and breast cancer: facts and presumptions for consideration. Ecancermedicalscience 9: 557, 2015.

15. Stull VB, Snyder DC, Demark-Wahnefried W. Lifestyle interventions in cancer survivors: designing programs that meet the needs of this vulnerable and growing population. J Nutr 137: 243S-248S, 2007.
16. Schmitz KH, Courneya KS, Matthews C, et al. American College of Sports Medicine roundtable on exercise guidelines for cancer survivors. Med Sci Sports Exerc 42: 1409-1426, 2010.

17. Velthuis MJ, Agasi-Idenburg SC, Aufdemkampe G, et al. The effect of physical exercise on cancer-related fatigue during cancer treatment: a meta-analysis of randomised controlled trials. Clin Oncol (R Coll Radiol) 22: 208-221, 2010.

18. Brown JC, Huedo-Medina TB, Pescatello LS, et al. Efficacy of exercise interventions in modu-lating cancer-related fatigue among adult cancer survivors: a meta-analysis. Cancer Epidemiol Bio-markers Prev 20: 123-133, 2011.

19. Cramp F, Byron-Daniel J. Exercise for the management of cancer-related fatigue in adults. Cochrane Database Syst Rev 11:CD006145, 2012.

20. Mohammadi S, Sulaiman S, Koon PB, et al. Impact of healthy eating practices and physical activity on quality of life among breast cancer survivors. Asian Pacific J Cancer Prev 14: 481487, 2013.

21. Phillips SM, McAuley E. Physical activity and quality of life in breast cancer survivors: the role of self-efficacy and health status. Psycho-Oncology 23: 27-34, 2014.

22. Schmidt ME, Wiskemann J, Armbrust $P$, et al. Effects of resistance exercise on fatigue and quality of life in breast cancer patients undergoing adjuvant chemotherapy: A randomized controlled trial. Int J Cancer 137: 471-480 , 2015.

23. Canário AC, Cabral PU, de Paiva LC1, et al. Physical activity, fatigue and quality of life in breast cancer patients. Rev Assoc Med Bras 62: 38-44, 2016.

24. Saarto $\mathrm{T}$, Penttinen HM, Sievanen $\mathrm{H}$, et al. Effectiveness of a 12-month exercise program on physical performance and QOL of breast cancersurvivors. Anticancer Res 32: 38753884, 2012.

25. Adamsen L, Quist M, Andersen C, et al. Effect of a multimoda high intensity exercise intervention in cancer patients undergoing chemotherapy: randomized controlled trial. BMJ 339: b3410, 2009.

26. Baumann FT, Bloch W, Weissen A, et al. Physical Activity in Breast Cancer Patients during Medical Treatment and in the Aftercare - a Review. Breast Care 8: 330-334, 2013.

\section{Correspondence:}

Haleh GHAVAMI

Nik Alley-Neshat-Bargh Street

No: 25

zip: 5715694133

URMIA / IRAN

Tel: (+98-914) 3416092

Fax: (+98-443) 2754921

e-mail: haleh_ghavami@yahoo.co.uk 